\title{
Using PQRST Strategy and Powtoon Media To Improve Students' Reading
} Engagement

\author{
Pratidina Parameswari \\ dinaparameswari@gmail.com \\ Ikhsanudin Ikhsanudin \\ ikhsanudin@fkip.untan.ac.id \\ Zainal Arifin \\ zamz_dozen@yahoo.com
}

\section{Universitas Tanjungpura, Pontianak}

\begin{abstract}
The main objective of this research was to find out the improvement of students' engagement in reading comprehension of descriptive text using PQRST Strategy and PowToon media to the seventh grade students of SMP Negeri 3 Sungai Raya in academic year 2019/2020. This classroom research was conducted in three cycles. The subject of this research was 32 students in class VII E. The researcher used observation checklist, field notes and reading tests as tools of data collection. The improvement of students' engagement improvement could be seen was reflected byfrom their students' performance in the teaching and learning process. The students became more enthusiastic in following participating in the lesson because they worked in group with their friends. The teacher gave a PQRST learning $\log$ to each groups as a guide during the stage of PQRST strategy shown in PowToon media. Preview, the students guess the topic by read the title and the pictures. Question, the students made questions based on they were interested in Preview stage. Read, the students read the whole text while looking for the answers of their own questions, they also wrote the difficult words found. State, the teacher and the students discussed about the contents of the text and the difficult words. The students have also take turn presented the results of their group's work with their own words. Last in Test the teacher gave the students multiple choice to make sure they understood the text clearly. Those activities make students more active during the class, so their reading engagement was improved.
\end{abstract}

Keywords: Students' engagement; PQRST strategy; PowToon media 


\section{INTRODUCTION}

Reading is an activity for understanding certain written language information. Learners can gain new knowledge by reading, and they can open up the world from the many sources of information they need. Reading is a process of absorping information from the writer to the reader through written text. For EFL (English Foreign Language) learners, developing reading comprehension is hard. Students should improve their comprehension by using appropriate teaching strategy for reading comprehension. Mikulecky, Beatrice, Jeffries, and Linda (2007, p.74) state in order to understand what students read, understanding is more than just recognizing and reading words. It also requires understanding what idea has been read by the students. Reading comprehension is the process of making meaning from text. The students should know clearly the meaning of the text (G. Woolley, 2011). In other words, comprehending means thinking while the reading process by the students.

Descriptive text is one of the material in the syllabus for the seventh grade students of junior high school. Descriptive text is a text that describes a person or article, include of structure, nature, number or otherwise. The aim of reading descriptive text is to understand clearly the details of things around us such as people, animals, locations, or things that they can easier developing the idea of what is being discussed in the text, or the reader can feel that they are part of the object (KangGuru, 2005). It means that the purpose of the descriptive text, either abstract or concrete, is obviously to describe represent or reveal a person or an object.

Our two months participarory observation at SMP Negeri 3 Sungai Raya in Kubu Raya Country found that the students experience challenges in reading descriptive text when attending English classes. Most students did not well in doing exercises. They could not determine main ideas and supporting details. In general, they did not understand the meaning of the texts that they should read. Their behaviour in the classroom also showed that they were not enthusiastic in English subject and did not pay excellent attention when the teacher gave explanation. Many students could not understand the instruction in the book or paper of task by themselves. They definitely asked the meaning of almost every single the teacher because. It reflected that they did not really do their best to read and to open consult dictionaries. Based on the interview with the English teacher, we found that many students could not reach at least the minimum score of 75 in their previous semester assessment.

The researcher also found that students did not really concerned when the teacher gave the material. Most of student read the text while putting their head on the table or propping the heads with their hands. In fact, the students did not look enthusiastic and curious about the text. At this point, students' engagement is important to motivate students in reading the text. Charbel Semaan and Nour Ismail (2018) state to achieve appropriate learning styles and to increase motivation in public schools, it takes extensive preparation to engage students who have developed learning 
disabilities to learn English as a foreign language. The teacher's teaching method cound be one of the problems. The teacher taught reading by just by giving texts and comprehension questions. The learners were asked to answer the questions in groups and individually. There was not particular technique that was introduced to the students. As a result, it was difficult for the students to understand the text and to accomplish the tasks.

One of the most critical factors in teaching and learning process is the students' engagement (Ikhsanudin, 2017). The researchers found it possible to improve the quality of the teaching and learning process by inviting the students' engagemen to learn reading English text. Using a particular reading technique that was combined with a teaching media would be good do so. This research was conducted improve students' reading engagement using PQRST strategy and PowToon media. Reading comprehension can be improved by using certain strategies in the form of learning skills. One of the learning strategies that are widely used to improve students' understanding, especially in the field of reading content, is PQRST, which stands for Preview, Question, Read, Summarize, and Test. It is based on work by Ahuja and Ahuja (2007:21). The PQRST strategy is a study reading strategy that helps students carry out textbook material in a strategic manner. It is designed to help students optimise their reading and learning. At this point, PowToon offers a wide range of media to create engaging lesson plans that dealing with visual and auditory learners while following a logical sequence. According to Nafarupita (2017), PowToon is an application for making simple animated videos for presenting material in varied, unique, and fun way according to the level of imagination and creation. It used to attract attention from the students.

The purpose of this research was to know how PQRST Strategy and PowToon media improved students' reading engagement. To conduct this research, the researcher applied a Classroom Action Research (CAR) to find out that using PQRST strategy and PowToon media can improve students' reading engagement. Regarding to the agreement from the English teacher of seventh grade students of SMP Negeri 3 Sungai Raya, this research was conducted in class VII E. The researcher hopes that this research will provide other people with long-term benefits, particularly for teachers with students having trouble reading descriptive text.

\section{LITERATURE REVIEW}

\section{Previous Study}

Ikhsanudin, Sudarsono, and Urai Salam (2019 were conducted the study at the College of Teacher-Training and English Education Study Program of Universitas Tanjungpura (FKIP UNTAN). The study was conducted to purpose of the research is improving improve the students' engagement in a listening class through a set of "magic tricks" problem-based activities. The activities in the class were conducted implemented in groups and whole class. After the magic trick activities were 
combined with group discussions, it was found that students' engagement improved when that the the students were involved in problem-solving discussion, particularly when they were asked to figure out and explain the tricks behind the magic. It means that a creative teaching technique in CAR could improve students' engagement. The use of magic tricks created fun atmosphere in the classroom, it made the students optimize their learning.

Susanti (2013) used classroom action research in her next study, which included eleventh-grade students from SMA PIRI 1 Yogyakarta as participants. The actions included in this study were the discussion of new vocabulary items and the implementation of the PQRST strategy, the choice of everyday meaning for subjects, the conduct of the game and the application of group work. And it proven that PQRST strategy improved students reading comprehension and enhanced students' motivation in reading.

The other research conducted by Entis Sutisna, Lungguh Halira Vonti, Septian Agung Tresnady (2019) which used descriptive method. The study's goal is to discover students' perceptions and challenges in the teaching and learning process using PowToon software. The research participants are first semester students in Pakuan University's Faculty of Teacher Training and Educational Science's English Language Education Study Program. According to their findings, PowToon can assist students in comprehending the material. As a result, learning through animated videos from PowToon makes the learning process more enjoyable. Through a PowToon animated video, the researcher discovered that each student mentioned their own perspectives and challenges in learning the text. The perspective and challenges of each student are expressed in different words but point to the same core. On the other hand, students need to concentrate more on the material itself.

\section{Students' Engagement}

Students' engagement is a basis learning motivation for students. More than just participation, engagement necessitates emotion, common sense, and action. (Harper and Quaye, 2009). According to Ikhsanudin, Sudarsono, and Urai Salam (2019) it is generally accepted that it is difficult to get students interested in classroom activities. The students' engagement is difficult to achieve and sustain. However, it still has to be handled for good teaching. Barkley (2009) describe that students' engagement are passion and excitement. She also stated that students' engagement is interaction between motivation and active learning. Trowler (2010) involve three aspects of Engagement: 1) Behavioural engagement, the level of student motivation shown in classroom learning and educational activities outside of the classroom is determined by behaviour. Behaviours can range from simple tasks such as doing assigned work, accepting school laws, and being involved in organizations of schools. 2) Emotional engagement, it requires positive and negative responses to teachers, students or schools, and it is assumed that school relationships are built and the ability to do work is influenced. An affective reaction shown by class 
students is emotional involvement. This affective response is reflected in feelings of pleasure, sorrow, anxiety, frustration and interest in classroom learning. 3) Cognitive engagement, which refers to the concept of investment; it includes being wise and willing to make the effort necessary to grasp complex ideas and master difficult skills. When students could repeat the material given, summarize, describe and comprehend the material presented, cognitive engagement is seen.

\section{PQRST strategy}

The aims of using PQRST strategy on reading comprehension is to understand some of the elements which is contained in a text. PQRST strategy is designed for helping students to optimize their reading. According to Ismiyati (2017), PQRST can influence students' comprehension when reading a text or information because it includes steps that encourage students to be more active in comprehending the text. This means that PQRST is a good strategy because it allows students to retrieve data from their memory after reading. The PQRST strategy can be used to help readers understand and prioritize information in a way that is directly related to how they will be asked to use that information (Simatupang and Sihombing, 2012). According to Wormeli, as cited by Susanti (2013: 27), the PQRST Literacy Strategy consists of five steps: 1) Preview. During the previewing step, students identify key parts of the text. 2) Question, the teacher creates questions for the students to answer. 3) Students read the entire text. While reading the text, students may encounter difficulties or learn new vocabulary. 4) Students will state the main idea or theme of the reading text. 5) Test, in this step, the researcher assessed the student's understanding by administering a test.

\section{PowToon}

PowToon is a web-based animation software that allows users to create and deliver animated presentations. According to Nafarupita (2017) PowToon is an application for making simple animated videos for presenting material in varied, unique, and fun way according to the level of imagination and creation. Tracy Weber (2014) states PowToon can be used to teach any subject, paving the way for thinking skills that are basic skills for this century, such as critical thinking, summarizing, and problem solving. PowToon is a creative platform that lets users arrange awesome videos and animated presentations (Crunchbase, 2011). In addition, HamiltonHankins, O. (2017) state PowToon gives positive impact as a technological tool including instructional practices and students' engagement levels in the classroom. PowToon represents creativity and produces meaningful and memorable learning experiences, many interesting features in PowToon such as cartoon characters, animated models and other interesting objects that make this software very suitable for making teaching media to create relaxed and fun atmosphere for students in the classroom. 


\section{METHOD}

\section{Design and Samples}

The researcher used Classroom Action Research as the research methodology in this study. This Classroom Action Research (CAR) employs Kemmis and Taggart design. According to Kemmis and MC Taggart (as cited in Burns, 2010), there are four stages. The first is planning phase, it is about preparation for teaching and learning process. It should be based on the problem that have identified before. The second phase is the acting phase, in which both the researcher and the teacher work together to carry out the planned action. Third, the observing phase, in which the researcher and the teacher collaborate to write down all events that occur in the classroom from the beginning to the end. The fourth phase is the reflecting phase, which is intended to reflect or evaluate the three previous phases. The seventh grade students at SMP Negeri 3 Sungai Raya in the academic year2019/2020 were the subjects of this study. The research was conducted in class VII E that consists of 32 students because the students in this class having problem in low participation learning process, especially in reading comprehension on descriptive text.

\section{Instrument and Procedures}

In order to support the research data, two techniques of data collection were used in this study: observation and measurement tests. The researchers are interested in studying and quantifying some type of behavior, interaction, or event that occurs, observation is an efficient way to collect data. The purpose was to observed the process in order to improve the result and to repair the mistakes of the process. At the end of the lesson, the researcher gave some measurement test to see the students' progress in reading comprehension. In the observation, the researcher used observation checklist and field note. Observation checklist is a list of things that an observer is going to look at when observing activities in a class. It has several contents be given a checklist $(\sqrt{ })$. The contents will describe the activity of the students during the teaching and learning process. Field note is a note, which is will use to record the important events that happen in teaching learning process when the treatment is applied to support the data from observation checklist. At the end of the lesson, measurement test will use to see the students' progress in terms of their reading comprehension skill, a test will be used as instrument.

The implementation of the PQRST strategy and PowToon media is explained in four stages of classroom action research. The researcher and teacher first discussed the PQRST (Preview, Question, Read, State, Test) strategy and how it was used to improve students' reading comprehension on descriptive text. Following that, the researcher has prepared data collection tools such as an observation checklist and a field note. The lesson plan, material learning media, and assessment sheet were also created by the teacher and researcher. In the second phase, the teacher used PowToon media to explain the PQRST (Preview, Question, Read, State, Test) strategy to the students and demonstrated how the strategy was implemented in the 
classroom. In addition, the researcher became an observer of the activity. The third phase involved the researcher observing what happened during the activity, how the strategy works, how the students and teacher behave, and whether or not the strategy could solve the problem. All of the findings were documented in an observation checklist and a field note. In the fourth phase, it is done based on the data that has been collected in order to hold an evaluation for the next cycle to be completed. As a result, the reflection can be determined after the action and observation outcomes have been implemented. If problems are still discovered, the cycle must be repeated until the problems are resolved. In the final stage, the researcher and the teacher discussed the outcome, and the researcher analyzed the strengths and weaknesses of this strategy.

\section{Data Analysis}

The data analysis technique used in this study is qualitative data supported by quantitative data. The data collected from students' multiple-choice responses is analyzed by the researcher. Therefore, to solve the problem of this research, the researcher uses this formula of the data analysis:

$$
\mathbf{M}=\frac{\sum \chi}{\mathrm{N}} \quad \begin{aligned}
& \text { Explanation: } \\
& \mathrm{M}=\text { the average of students score } \\
& \\
& \begin{array}{l}
\sum^{\chi}=\text { total score } \\
\mathrm{N}=\text { the number of students }
\end{array}
\end{aligned}
$$

Mean of score from one cycle will be compare with mean of three cycles. It is also to know how for the progress of students in this research. To clarify the data of measurement test, the researcher provides following measurement:

Table 1. Criteria for Students' Score

\begin{tabular}{|c|c|c|}
\hline Score & Predicate & Criteria \\
\hline $93-100$ & A & Very good \\
\hline $84-92$ & B & Good \\
\hline $75-83$ & C & Average \\
\hline$<75$ & D & Poor \\
\hline
\end{tabular}

(Kemdikbud, 2017)

\section{RESULTS AND DISCUSSION}

Based on the findings during Cycle 1 to Cycle 3, which had been carried out for three meetings, the results of Cycle 3 indicate that the improvement of teaching and learning process is getting better. Referring to the data of observation, teaching and learning process was satisfied. The students' engagement percentage from the first cycle to the third cycle was showed below as follow: 
Table 2. Percentage of Students' Engagement from The First Cycle to The Third

\begin{tabular}{|l|c|c|c|}
\hline \multicolumn{4}{|c|}{ Cycle } \\
\hline Aspect & Cycle 1 & Cycle 2 & Cycle 3 \\
\hline Emotional & $53.1 \%$ & $64 \%$ & $75 \%$ \\
\hline Cognitive & $13 \%$ & $32.9 \%$ & $50.5 \%$ \\
\hline
\end{tabular}

In the first cycle, the result of students' engagement was specified into $53.1 \%$ behavioral aspect, $13 \%$ emotional aspect, and $14.5 \%$ cognitive aspect. The result of students' engagement in the second cycle specified into $64 \%$ behavioral aspect, $32.9 \%$ emotional aspect, and $33.8 \%$ cognitive aspect. In the third cycle the students' engagement was specified into $75 \%$ behavioral, $50.5 \%$ emotional, and $53.6 \%$ cognitive. It showed that students' engagement was improved.

Based on the observation and analysis of the students' engagement in reading descriptive text, it was found that students' reading comprehension in descriptive text had improved by using PQRST Strategy and PowToon media. PQRST strategy and PowToon media solved students' problem in developing their information through guessing the information and explore the supporting information that is related to the material. PQRST strategy and PowToon media also improved students' skill in organizing the information through seeing the clues shown on PowToon media.

During the teaching and learning process, many students were interest in learning and they became more curious to know the new topic of text. Some other students participated active than in previous meeting especially when filling the PQRST learning log which have given from the teacher. On the other situation, many students looked enthusiastic in discussing with their group after watching the PowToon media. The teacher showed pictures from PowToon media in Preview stage, there were also some clues to let the students guess about the topic and make they more enjoyed and feeling fun atmosphere in the class. The students' responses were excited when teacher give the topic. In this section, there were more information and guides to make the students easier to understand. In making question, the students' easier to make a question about what they want to know and the students bravely expressing their idea. They seemed look enthusiastic in guessing the topic based on the explanation of PQRST from PowToon media. It can be seen from the students' reaction raising their hands. And in test, the students seemed calmer and most of students improved in their individual score. The students' mean score from the first cycle to the third cycle was showed below as follow: 
Table 3. Mean Score of Students' Engagement from the First Cycle to the Third

\begin{tabular}{|c|c|c|}
\hline Cycle 1 & Cycle 2 & Cycle 3 \\
\hline 42.5 & 60.25 & 82.81 \\
\hline Poor & Poor & Average \\
\hline
\end{tabular}

The mean score of students in the first cycle was 42.5, it categorized Poor. In the second cycle the mean score of students was getting better. Even though it still declines into the same category Poor with score 60.25. For the third cycle, the mean score of students was categorized average. It was improved with score 82.81 .

According to the previous research conducted by Susanti (2013) the use of game is proven to improve students' reading skills. In this research the researchers used a guessing game in implementing the PQRST strategy through PowToon media in order to attract students' attention. Evidently, it creates a pleasant situation in the classroom similar to a research conducted by Ikhsanudin, Sudarsono, and Urai Salam (2019). Through fun activity, students become exciting, focused and enjoy the learning process. Therefore, students' reading engagement can improve.

The difference between this research and other researches is using the learning log in implementing the PQRST strategy through PowToon Media. The use of learning $\log$ serves to organize students' ideas so that they are structured and centered without making students confused. Learning log can help students more confident in expressing their ideas and make students interested in reading. During the implementation of the PQRST strategy and PowToon media, the learning log used as a guide in understanding the content of the text. While watching the PQRST strategy through PowToon media step by step, students can follow it easily because there is already an instruction in each step. This can also eliminate students' boredom in following the learning process.

In conducting this research, the researcher totally conducted three cycles until the researcher felt satisfied to the result. The researcher applied classroom action research as the method of this study, where each cycle had four stages to be applied such as planning stage, acting stage, observing stage and reflecting stage. In this study, the researcher did collaboration with the English teacher of class VII E. During the teaching and learning process, the researcher acted as the collaborator and observer of the activity, while the teacher acted as the teacher to teach students reading comprehension in descriptive text using PQRST strategy and PowToon media by following the lesson plan already prepared by the researcher and agreed by the teacher. The students showed progression for the score and their behavior during teaching and learning process from the first cycle to the third cycle. Based on the data of observation, students' engagement was improved from cycle to cycle. It can be seen from the chart below: 


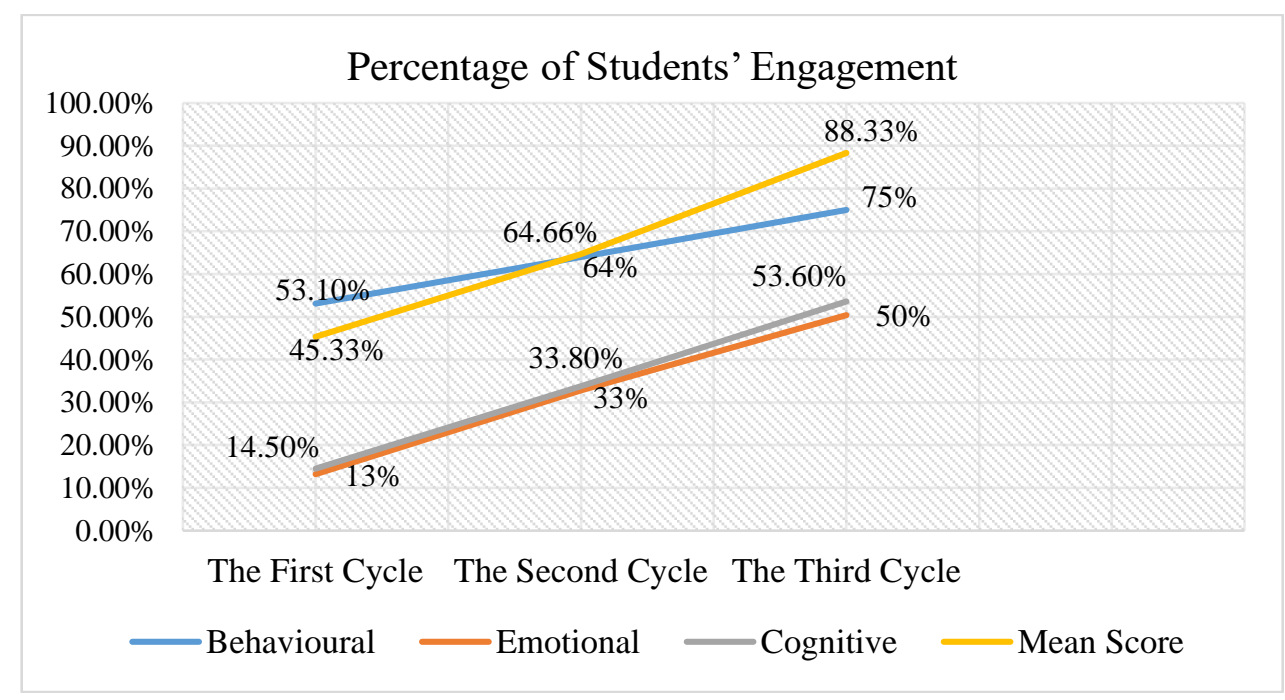

Figure 1. Percentage of Students' Engagement from The First Cycle to The Third Cycle

In the first cycle, the students' engagement was specified into $53.1 \%$ of behavioral, $13 \%$ of emotional, and $14.5 \%$ of cognitive. It showed that half of students behavioral engaged. In the second cycle, the students' engagement was specified into $64 \%$ behavioral aspect, $32.8 \%$ emotional aspect, and $33.8 \%$ cognitive aspect. It presented that there was an improvement of second cycle. In the third cycle, the students' engagement was specified into $75 \%$ behavioral aspect, $50.5 \%$ emotional aspect, and 53.6\% cognitive aspect. In addition, the students who could reach the average scores were $45.33 \%$ in the first cycle, $64 \%$ in the second cycle, and $75 \%$ in the third cycle.

The PQRST strategy and PowToon media contribute the problem solving process for students where students begin to building ideas from PowToon media views and pouring them into the PQRST learning log to prepare on reading descriptive texts. The design of material by using PowToon media was suitable with the students' level. The students enthusiastic especially at the guessing part when the clues of the topic in each section of the PQRST strategy are displayed on PowToon media. It made the students focus and enjoy because there were fun atmospheres during the class. The students' response was excited in previewing the topic, they also bravely expressing their idea. The students participate actively to offering ideas and questions. Many students were interest in learning, they became more curious and also almost all the students could answer the test completely at the end.

\section{CONCLUSION}

Based on the research findings, the action of the three cycles can be concluded that PQRST strategy and PowToon media improved students' engagement in reading a descriptive text. The improvement of students' engagement can be seen from students' positive behaviour, students' reaction of emotion, and the students' 
cognitive in provides the ideas including completed the task. The improvement of students' engagement was start by developing ideas from PowToon media views and pouring them into the PQRST learning log to prepare on reading descriptive texts. The details information in PowToon media makes the students easier doing the PQRST strategy in reading. The students showed enthusiasm by raising hands and asking the teacher. The students became enjoy in the class. They seemed look more enthusiastic than before. The students became more attractive because they were like to guessing the material based on the PQRST strategy in PowToon media. It became fun situation and made students focus during the class. Almost all students have done the text completely. They were also supported by the PQRST learning $\log$. The use of the learning log is very helpful in making students be brave and confident in developing their thinking after reading the text.

\section{REFFERENCES}

Ahuja, P. \& Ahuja, G.C. (2007). How to read effectively and efficiently. New Delhi: Sterling.

Barkley, Elizabeth F. (2009). Engagement Technique: A Handbook for College Faculty. JOSSEY-BASS

Beatrice, S., Mikulecky, \& Linda Jeffries. (2007). Advanced reading power, New York, NY: Longman.

Charbel, S., \& Nour, I. (2018). The Effect of Using PowToon on learning English as a foreign language. International Journal of Current Research, 10, (05), 69262-69265.

Crunchbase. (2011). PowToon. Retrieved April 5, 2019 from https://www.crunchbase.com/organization/powtoon\#section-overview

Hamilton-Hankins, O. J. (2017). The Impact of Technology Integration on the Engagement Levels of Ten Second Grade Students in an English Language Arts Classroom. Doctoral dissertation. Retrieved from https://scholarcommons.sc.edu/etd/4343

Harper, S. R. \& Quaye, S.J. 2009 (a), "Beyond Sameness, with Engagement and Outcomes for All" in Student Engagement in Higher Education, eds. S.R. Harper \& S.J. Quaye, Routledge, New York \& London, pp. 1-15.

Ikhsanudin, I. (2019) The Possibility of Developing English Magic Tricks ProblemBased Activities to Enhance Senior High School Students' Engagement. ICoTE Proceedings, 1(1), pp. 28-34. Retrieved from https://jurnal.untan.ac.id/index.php/icote/article/view/26196.

Ikhsanudin, I. Sudarsono, S., \& Salam, U. (2019) Using magic trick problem-based activities to improve engagement in a listening class. JELTIM: Volume 1 April 2019 - Number 1. 
Ismiyati, T. (2017). Improving Students' Ability in Reading Comprehension by Using Preview, Question, Read, State and Test Strategy. Thesis. Medan: State Islamic University.

KangGuru in the Classroom (2005) Teacher's Guide SMA Package. Bali: IALF $\begin{array}{llll}\text { Retrieved April } & \text { 4, } & \text { from }\end{array}$ https://teachingenglish4all.wordpress.com/2010/06/28/descriptive-text/

Kemendikbud. (2017). Panduan Penilaian oleh Pendidik dan satuan Pendidikan untuk Sekolah Menengah Pertama (Edisi Revisi). Jakarta: Kementerian dan Kebudayaan Direktorat.

Kemmis \& Mc. Taggart. (2010). The Action Research Planner. Geelong: Deaken Univercity Press.

Nafarupita. (2017). Apa Itu PowToon? Retrieved April 5, 2019 from http://nafarupita.blogspot.com/2017/04/apa-itu-powtoon.html

Simatupang, L., \& Sihombing, L. (2012). The Effect of PQRST Method on Students' Reading Comprehension of Descriptive Text. Retrieved from https://jurnal.unimed.ac.id/2012/index.php/elt.

Susanti, A. N. R. (2013) Improving students' reading comprehension through PQRST technique. Thesis. Yogyakarta State University.

Sutisna, E, Lungguh, H.V, Septian, A.T. (2019). The use of PowToon Software Program in teaching and learning process: The students' perception and challenges. JHSS, 03(02).81-85.

Trowler, V. (2010). Student Engagement Literature Review (November 2010). Lancaster University, Department of Educational Research. Lancaster: The Higher Education Academy. Retrieved from htts://www.heacademy.ac.uk/system/files/studentengagementliteraturerevi ew_1.pdf

Weber, T. (2014). Tools for Teachers and Students. Techniques: Connecting Education \& Careers, 89(3), 8

Woolley, G. (2011), Reading comprehension: Assisting children with learning difficulties. London: Springer Science Business Media B.V 